Article

\title{
One-Step Extraction of Antimony in Low Temperature from Stibnite Concentrate Using Iron Oxide as Sulfur-Fixing Agent
}

\author{
Yun Li ${ }^{1}$, Yongming Chen ${ }^{1, *}$, Haotian Xue ${ }^{2, *}$, Chaobo Tang ${ }^{1}$, Shenghai Yang ${ }^{1}$ and Motang Tang ${ }^{1}$ \\ 1 School of Metallurgy and Environment, Central South University, Changsha 410083, China; \\ li-yun@csu.edu.cn (Y.L.); chaobotang@163.com (C.T.); yangshcsu@163.com (S.Y.); \\ tangmotangcsu@163.com (M.T.) \\ 2 Qinghai Provincial Research and Design Academy of Environmental Sciences, Xining 810000, China \\ * Correspondence: csuchenyongming@163.com (Y.C.); haotianx@sina.cn (H.X.); \\ Tel./Fax: +86-731-8883-0470 (Y.C.); +86-971-8172-559 (H.X.)
}

Academic Editor: Corby G. Anderson

Received: 28 April 2016; Accepted: 16 June 2016; Published: 7 July 2016

\begin{abstract}
A new process for one-step extraction of antimony in low temperature from stibnite concentrate by reductive sulfur-fixation smelting in sodium molten salt, using iron oxide as sulfur-fixing agent, was presented. The influences of molten salt addition and composition, ferric oxide dosage, smelting temperature and duration on extraction efficiency of antimony were investigated in details, respectively. The optimum conditions were determined as follows: 1.0 time stoichiometric requirement $(\alpha)$ of mixed sodium salt $\left(\alpha_{\text {salt }}=1.0\right), W_{\mathrm{NaCl}}: W_{\text {salt }}=40 \%, \alpha_{\mathrm{Fe}_{2} \mathrm{O}_{3}}=1.0$, $W_{\text {coke }}: W_{\text {stibnite }}=40 \%$, where $W$ represents weight, smelting at $850{ }^{\circ} \mathrm{C}(1123 \mathrm{~K})$ for $60 \mathrm{~min}$. Under the optimum conditions, the direct recovery rate of antimony can reach $91.48 \%$, and crude antimony with a purity of $96.00 \%$ has been achieved. $95.31 \%$ of sulfur is fixed in form of FeS in the presence of iron oxide. Meanwhile, precious metals contained in stibnite concentrate are enriched and recovered comprehensively in crude antimony. In comparison to traditional antimony pyrometallurgical process, the smelting temperature of present process is reduced from $1150-1200{ }^{\circ} \mathrm{C}(1423-1473 \mathrm{~K})$ to 850-900 ${ }^{\circ} \mathrm{C}(1123-1173 \mathrm{~K})$. Sulfur obtained in stibnite is fixed in FeS which avoids $\mathrm{SO}_{2}$ emission owing to the sulfur-fixing agent. Sodium salt can be regenerated and recycled in smelting system when the molten slag is operated to filter solid residue. The solid residue is subjected to mineral dressing operation to obtain iron sulfide concentrate which can be sold directly or roasted to regenerate into iron oxide.
\end{abstract}

Keywords: stibnite concentrate; extraction of antimony; reductive sulfur-fixing smelting; low-temperature; molten sodium salt

\section{Introduction}

China has abundant reserves of antimony resource and it's also the largest producer of antimony in the world. Generally, the technologies for producing antimony mainly comprise pyrometallurgy and hydrometallurgy [1,2]. Pyrometallurgy routes for extraction of antimony typically contain roasting-volatilizing-reducing process, bath smelting-continuous fuming process [3] and direct smelting process $[4,5]$. While hydrometallurgy technologies for antimony separation can be classified into alkaline extraction procedure and acidic extraction process according to property of solvents. Alkaline extraction procedure primarily adopts $\mathrm{Na}_{2} \mathrm{~S}$ leaching followed by membrane electrowinning [6]. Acidic extraction process mainly includes $\mathrm{FeCl}_{3}$ leaching-electrowinning and chlorination-distillation procedure [1]. At present, due to the lengthy flow, poor efficiency, high running cost and large amount of wastewater treatment during hydrometallurgical separation 
process [7] of antimony, most of antimony smelteries in China use traditional volatilization smelting process in blast furnace to volatilize the resultant antimony trioxide, and then reduce the trioxide with carbon to metallic antimony in reverberatory furnace. However, this process has its obvious drawbacks, such as serious environmental pollution and large energy consumption, which restrict its popularization and application, especially under the background of increasing stringent environmental standard. Therefore, renovation and innovation in traditional antimony metallurgy technology are imperative [8-10].

Our research group has done a great deal of investigations [11-14] and tried to modify and innovate the traditional antimony metallurgy. Some promising achievements have been acquired. Tang et al. [11] were based on the alkaline smelting presented by scholars [15] of the former Soviet Union and then used and developed this technique to smelt low-melting point nonferrous metals in $\mathrm{NaOH}-\mathrm{Na}_{2} \mathrm{CO}_{3}-\mathrm{Na}_{2} \mathrm{SO}_{4}-\mathrm{Na}_{2} \mathrm{~S}$ system, such as antimony, lead, bismuth and tin etc. They found that as long as the smelting temperature was adequately higher than corresponding metals' melting point, the extractive reaction would occur efficiently [11]. Yang et al. [12] separated 97.07\% antimony (96.45\% purity) from stibnite concentrate in $\mathrm{NaOH}-\mathrm{Na}_{2} \mathrm{CO}_{3}$ system at $880^{\circ} \mathrm{C}(1153 \mathrm{~K})$. Ye et al. [14] extracted $92.88 \%$ antimony (purity $93.17 \%$ ) in $\mathrm{Na}_{2} \mathrm{CO}_{3}-\mathrm{NaCl}$ system at $850{ }^{\circ} \mathrm{C}(1123 \mathrm{~K})$. However, the sulfur-fixing agent they used was $\mathrm{ZnO}$. Sulfur contained in stibnite concentrate was fixed in form of $\mathrm{ZnS}$. In this study, we developed a kind of alternative sulfur-fixing agent iron oxides.

Iron oxide-rich slags are produced in great deal in China [16,17], in particular pyrites cinder [18] generated in acid-making procedure. These residues generally store up in slag dumps and leave untreated. Considerable accumulation of these tailings not only occupies a large amount of land but causes contamination of the environment and constitutes an ecological threat to the surrounding life due to wind erosion and scattering in the regions. However, these kinds of residues are valuable secondary resource of iron. In addition, some precious metals, such as Au and Ag, frequently exist in pyrites cinder in China. The treatment of these massive quantities of residues is not only extraordinarily important but extremely necessary from both environmental and economic perspectives.

In this paper, the renovate process [12] (as shown in Figure 1) for antimony extraction from stibnite concentrate is proposed to overcome the problems in traditional two-step antimony metallurgy, meanwhile, to co-treat iron oxide-rich slags. This process is characterized by low temperature, elimination of $\mathrm{SO}_{2}$ emission and short flow. It consists of the following steps: feeding stibnite-containing feed, mixed sodium salt, sulfur-fixing agent and powdery coal or coke into a furnace with a temperature of less than $900{ }^{\circ} \mathrm{C}(1173 \mathrm{~K})$. As a result, crude antimony metal, ferrous sulfide, gangue, and regenerated molten salt, mainly containing sodium carbonate, are obtained. The regenerated molten salt is fed into the smelting furnace to reuse as the reaction flux again after filtering operation while it is melting state. The ferrous sulfide can be sold as ferrous sulfide concentrate or roasted to regenerate into iron oxide and used as sulfur-fixing agent again. The studies in this article were focus on the process illustrated in the frame in Figure 1. 


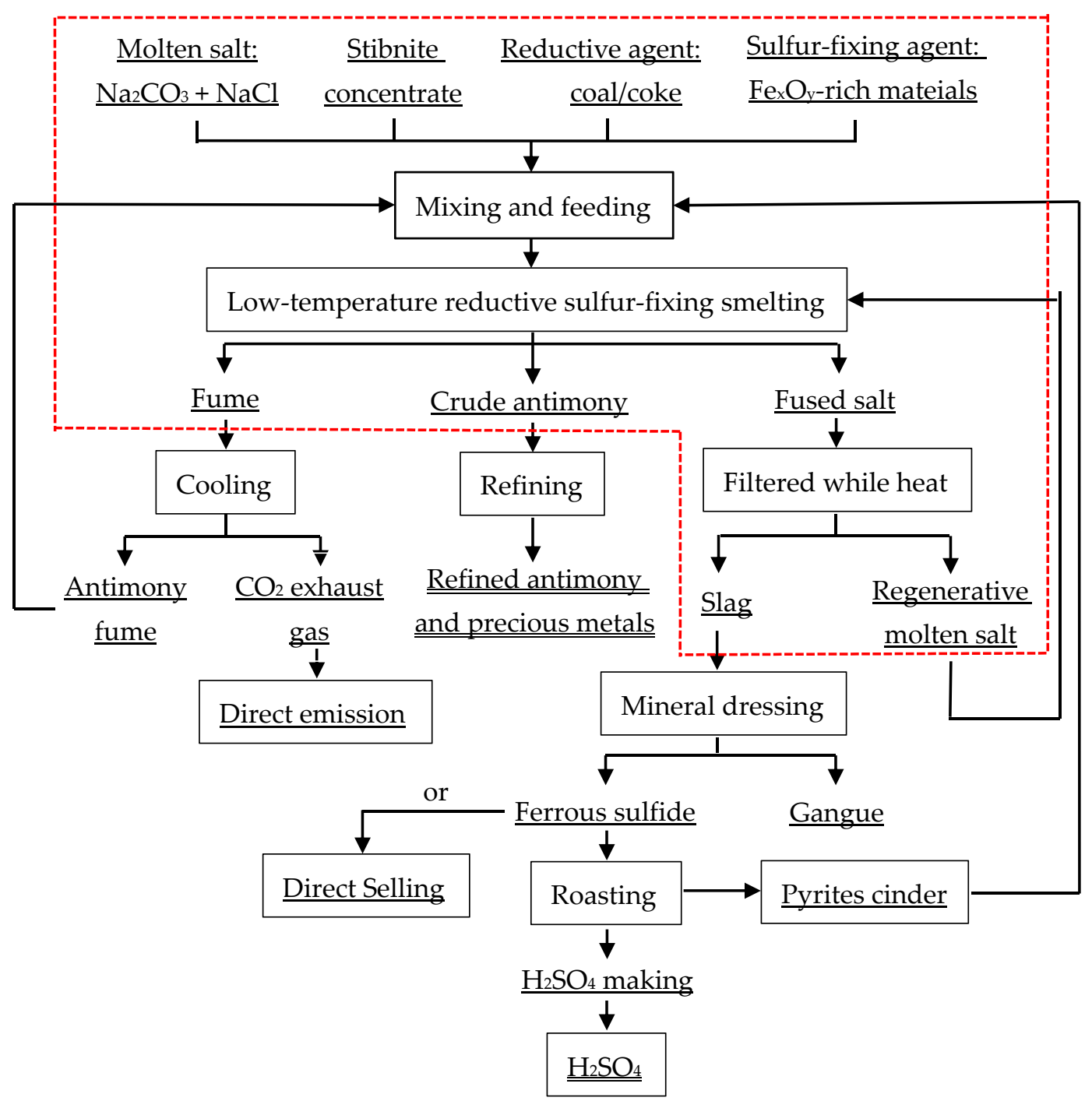

Figure 1. Flow sheet of reductive sulfur-fixing smelting of stibnite concentrate for one-step extraction of antimony in low temperature.

\section{Materials and Methods}

\subsection{Materials}

Stibnite concentrate used in this study obtained from Chenzhou Mining Group Co., LTD., Huaihua, Hunan, China. Powdered $\mathrm{Fe}_{2} \mathrm{O}_{3}, \mathrm{Na}_{2} \mathrm{CO}_{3}$ and $\mathrm{NaCl}$ with $>99.99 \%$ purity were purchased from Aladdin Industrial Corporation. Reductant, metallurgical coke, was provided by Xiangtan Iron and Steel Co., LTD. of Hunan Valin. Chemical compositions of stibnite concentrate were analysed by Inductively Coupled Plasma-atomic Emission Spectrometry (Perkin Elmer, Optima 3000 ICP-AES, Norwalk, CT, USA). The prior decomposition of stibnite concentrate was carried out in aqua regia (nitrohydrochloric acid, a 3:1 mixture of concentrated $\mathrm{HCl}$ and $\mathrm{HNO}_{3}$ aqueous solution) while shielded the influence of silica by hydrofluoric acid $\mathrm{HF}$ and perchloric acid $\mathrm{HClO}_{4}$. The results were presented in Table 1. 
Table 1. Chemical compositions of stibnite concentrate and coke used in experiments (mass fraction, \%).

\begin{tabular}{|c|c|c|c|c|c|c|c|c|c|c|}
\hline Materials/\% & $\mathrm{Sb}$ & $S$ & $\mathrm{Fe}$ & $\mathrm{Pb}$ & $\mathrm{Cu}$ & As & Bi & $\mathbf{A u}{ }^{*}$ & $\mathrm{SiO}_{2}$ & $\mathrm{CaO}$ \\
\hline $\begin{array}{c}\text { Stibnite } \\
\text { concentrate }\end{array}$ & 48.08 & 25.13 & 5.14 & 0.28 & 0.04 & 0.5 & $<0.01$ & 101.05 & 12.14 & 0.90 \\
\hline Reductant & 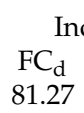 & $\begin{array}{c}\text { trial an } \\
\mathrm{V}_{\mathrm{d}} \\
3.3\end{array}$ & $\begin{array}{l}\text { sis } \\
\mathrm{A}_{\mathrm{d}} \\
15.43\end{array}$ & $\begin{array}{c}\mathrm{Fe}_{\text {total }} \\
25.23\end{array}$ & $\begin{array}{c}\text { temical } \\
\mathrm{MgO} \\
0.53\end{array}$ & $\begin{array}{c}\text { npositi } \\
\mathrm{SiO}_{2} \\
41.23\end{array}$ & $\begin{array}{c}\text { of the a } \\
\mathrm{CaO} \\
6.60\end{array}$ & $\begin{array}{c}\mathrm{Al}_{2} \mathrm{O}_{3} \\
25.24\end{array}$ & \multicolumn{2}{|c|}{$\begin{array}{c}\text { LOI } \\
82.79\end{array}$} \\
\hline
\end{tabular}

${ }^{*}$ means unit of Au content is $\mathrm{g} / \mathrm{t}$.

Phase compositions of stibnite concentrate were analysed by X-ray Diffraction (XRD, Rigaku 3014, Rigaku Corporation, Tokyo, Japan, $\mathrm{Cu}-\mathrm{K} \alpha$-radiation, $\lambda=1.54 \AA$ ) (as shown in Figure 2). It can be known that stibnite concentrate primarily comprises Sb 48.08\%, S 25.13\%, Fe 5.14\% and $101.05 \mathrm{~g} / \mathrm{t} \mathrm{Au}$, which attach a significant economic value to recover. Main phase compositions in stibnite concentrate are $\mathrm{Sb}_{2} \mathrm{~S}_{3}, \mathrm{FeS}$ and $\mathrm{SiO}_{2}$.

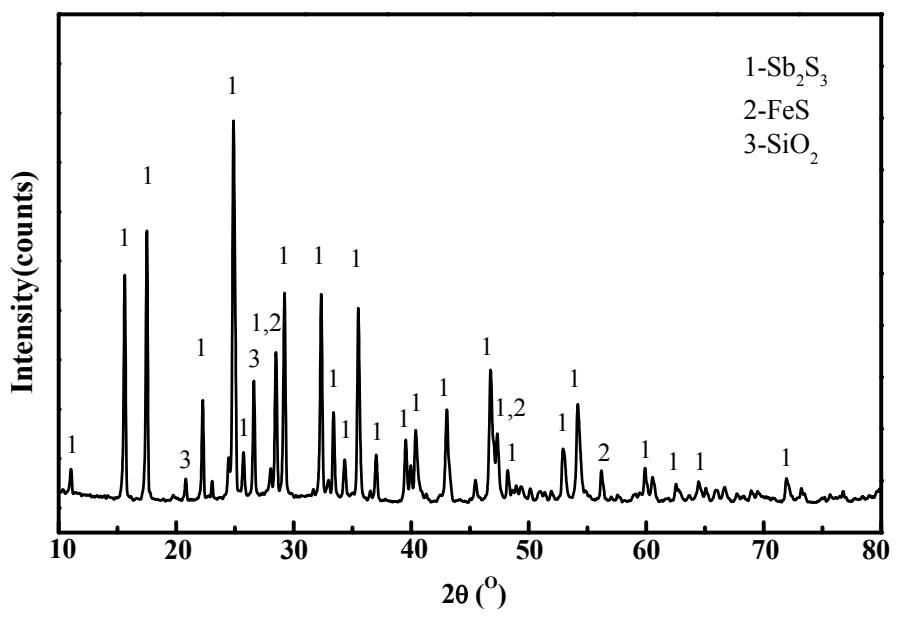

Figure 2. Phase composition of the stibnite concentrate.

\subsection{Methods}

As an experimental procedure, $100 \mathrm{~g}$ stibnite concentrate were mixed evenly with the given amount of coke, sodium carbonate and sodium chloride, sulfur-fixing agent $\mathrm{Fe}_{2} \mathrm{O}_{3}$ in every tests, and then the mixture were put into a weighed $100 \mathrm{~mL}$ corundum crucible. The crucible was placed in the constant temperature zone of furnace when the furnace temperature was raised to the desired value and held for preset time. After the smelting duration required, the crucible was taken out from furnace and cooled quickly. The product was put into a pre-prepared water $\left(50-85^{\circ} \mathrm{C}(323-358 \mathrm{~K}), \mathrm{L} / \mathrm{S}=(3-5): 1\right)$ for leaching $2-3 \mathrm{~h}$ to separate crude antimony and molten salt slag. Then the lixivium, leaching residue and crude antimony were measured and weighed carefully and sampled. Each of samples was crushed and well-prepared for analysis. The crude antimony solid samples were dissolved in dilute nitric acid. The leaching residue samples were dissolved in aqua regia while shielded the influence of silica. After dissolving the samples, the solid residue in the leaching solution was filtered using filter paper, and the obtained solution was subjected to ICP-AES (Perkin Elmer, Norwalk, CT, USA) analysis. Metals' recoveries were calculated based on the mass balance principle. In addition, the phase compositions of the molten salt slag before and after leaching were characterized by XRD respectively.

\subsection{Thermodynamic Considerations}

Antimony in stibnite concentrate generally exists in form of $\mathrm{Sb}_{2} \mathrm{~S}_{3}$. The melting point of metallic antimony is about $630.5^{\circ} \mathrm{C}(904 \mathrm{~K})$, and the melting point of the binary eutectic molten 
salt $\mathrm{Na}_{2} \mathrm{CO}_{3}-\mathrm{NaCl}[13]$ is around $632-645^{\circ} \mathrm{C}(905-918 \mathrm{~K})$. Under the smelting temperature, $\mathrm{Sb}_{2} \mathrm{~S}_{3} \mathrm{can}$ react with $\mathrm{Fe}_{2} \mathrm{O}_{3}$ and $\mathrm{Na}_{2} \mathrm{CO}_{3}$ respectively, and produces metallic antimony, $\mathrm{FeS}$ and $\mathrm{Na}_{2} \mathrm{~S}$. $\mathrm{Na}_{2} \mathrm{~S}$ then will continually react with $\mathrm{Fe}_{2} \mathrm{O}_{3}$ to regenerate $\mathrm{Na}_{2} \mathrm{CO}_{3}$. Sulfur is fixed in FeS ultimately. $\mathrm{NaCl}$ is not involved in any chemical reaction and just plays a role of inert reaction medium. The purpose of adding the chlorite into sodium carbonate is to form a lower-temperature mixed molten salt. The reaction mechanism can be briefly represented as follows (see Table 2):

Table 2. Main reactions occurred during reductive sulfur-fixing smelting of stibnite concentrate.

\begin{tabular}{ccc}
\hline Reaction & $\mathbf{G}_{\mathbf{T}}^{\prime}-\mathbf{T} \mathbf{~ ( k J / m o l ) ~ [ 1 9 ] ~}$ & Equation \\
\hline $\mathrm{Sb}_{2} \mathrm{~S}_{3}+1.5 \mathrm{Fe}_{2} \mathrm{O}_{3}+4.5 \mathrm{C}=2 \mathrm{Sb}+3 \mathrm{FeS}+4.5 \mathrm{CO}(\mathrm{g})$ & $\mathrm{G}_{\mathrm{T}}^{\theta}=-0.792 \mathrm{~T}+386.62$ \\
$\mathrm{Sb}_{2} \mathrm{~S}_{3}+1.5 \mathrm{Fe}_{2} \mathrm{O}_{3}+4.5 \mathrm{CO}(\mathrm{g})=2 \mathrm{Sb}+3 \mathrm{FeS}+4.5 \mathrm{CO}_{2}(\mathrm{~g})$ & $\mathrm{G}_{\mathrm{T}}^{\theta}=-0.0007 \mathrm{~T}-169.82$ \\
$\mathrm{Sb}_{2} \mathrm{~S}_{3}+3 \mathrm{Na}_{2} \mathrm{CO}_{3}+6 \mathrm{C}=2 \mathrm{Sb}+3 \mathrm{Na}_{2} \mathrm{~S}+9 \mathrm{CO}(\mathrm{g})$ & $\mathrm{G}_{\mathrm{T}}^{\theta}=-1.428 \mathrm{~T}+1056.2$ \\
$\mathrm{Sb}_{2} \mathrm{~S}_{3}+3 \mathrm{Na}_{2} \mathrm{CO}_{3}+3 \mathrm{CO}(\mathrm{g})=2 \mathrm{Sb}+3 \mathrm{Na}_{2} \mathrm{~S}+6 \mathrm{CO}_{2}(\mathrm{~g})$ & $\mathrm{G}_{\mathrm{T}}^{\theta}=-0.369 \mathrm{~T}+313.32$ \\
$\mathrm{Fe}_{2} \mathrm{O}_{3}+2 \mathrm{Na}_{2} \mathrm{~S}+1.5 \mathrm{CO}_{2}(\mathrm{~g})+0.5 \mathrm{C}=2 \mathrm{FeS}+2 \mathrm{Na}_{2} \mathrm{CO}_{3}$ & $\mathrm{G}_{\mathrm{T}}^{\theta}=0.146 \mathrm{~T}-249.96$ & $(3)$ \\
\hline
\end{tabular}

The Gibbs free energy $\mathrm{G}_{\mathrm{T}}^{\Theta}$ of reactions (1)-(5) were calculated under one atmospheric pressure. Figure 3 showed $\mathrm{G}_{\mathrm{T}}^{\ominus}$ and $\mathrm{T}$ diagram of it. It illustrats antimony reduction in the presence of ferrous oxide or sodium carbonate becomes thermodynamically favorable at range of smelting temperature 700-900 ${ }^{\circ} \mathrm{C}(973-1173 \mathrm{~K})$. Increasing temperature will promote the reactions (1) and (3) and (4) while decrease the positive trend of the reactions (2) and (5). $\mathrm{Sb}_{2} \mathrm{~S}_{3}$ is more likely to react with sulfur-fixing agent $\mathrm{FeO}$ instead of $\mathrm{Na}_{2} \mathrm{CO}_{3}$ to produce metallic antimony. $\mathrm{Na}_{2} \mathrm{CO}_{3}$ can regenerate and recycle through reaction (5). As a result, $\mathrm{Na}_{2} \mathrm{CO}_{3}$ will not be consumed during whole smelting system and act as a role of intermediate reactant. Ultimately, the mixed molten slat $\mathrm{Na}_{2} \mathrm{CO}_{3}-\mathrm{NaCl}$ can be recycled together after filtering away the slag. However, the presence of $\mathrm{Na}_{2} \mathrm{CO}_{3}$ and $\mathrm{NaCl}$ in smelting system significantly decreases temperature of reductive sulfur-fixing reactions.

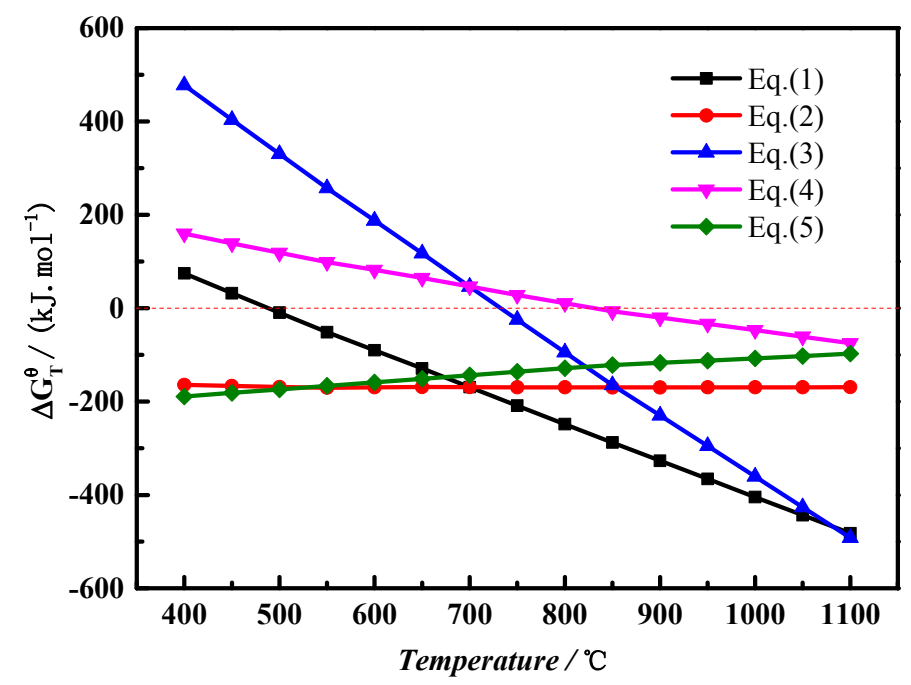

Figure 3. $G_{\mathrm{T}}^{\Theta}$ and $T$ diagram of reactions (1)-(5).

\section{Results and Discussion}

\subsection{Molten Salt Dosage}

The results of the influence of molten salt dosage on antimony recovery and resultant crude antimony grade are presented in Figure 4. All experiments were carried out under a temperature of $900{ }^{\circ} \mathrm{C}(1173 \mathrm{~K})$ for $180 \mathrm{~min}$, the charging composition of $100 \mathrm{~g}$ stibnite, $30 \mathrm{wt}$. \% coke of stibnite, 1.0 time stoichiometric requirement of sulfur-fixing agent $\mathrm{Fe}_{2} \mathrm{O}_{3}\left(\alpha_{\mathrm{Fe}_{2} \mathrm{O}_{3}}=1.0\right)$, calculated according to 
sulfur content in stibnite. The molten salt composition, which is the ratio of weight of sodium chloride to that of mixture of sodium carbonate and sodium chloride $\left(W_{\mathrm{NaCl}}: W_{\text {salt }}\right)$, is $10 \%$. The stoichiometric requirement of molten salt $\left(\alpha_{\text {salt }}\right)$ was calculated by Equation (3).

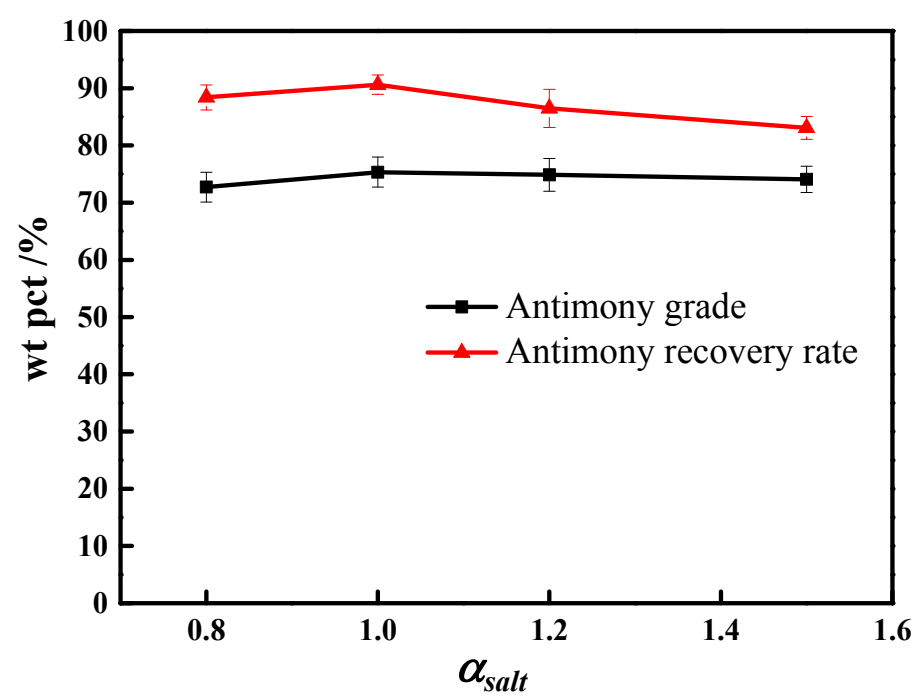

Figure 4. Influence of molten salt dosage on the recovery of antimony and antimony grade. $\left(W_{\mathrm{NaCl}}: W_{\text {salt }}=10 \%, \alpha_{\mathrm{Fe}_{2} \mathrm{O}_{3}}=1.0, W_{\text {coke }}: W_{\text {stibnite }}=30 \%, 900{ }^{\circ} \mathrm{C}(1173 \mathrm{~K}), 180 \mathrm{~min}\right)$.

Experimental results indicated that antimony recovery improved firstly and then decreased steadily as $\alpha_{\text {salt }}$ increased from 0.8 to 1.5 . Insufficient dosage of molten salt $\left(\alpha_{\text {salt }}=0.8\right)$ results in a poor fluidity of reaction melt in low temperature. As a result, the settling and accumulating of antimony particles is also inefficiency. Antimony recovery reached maximum value at $\alpha_{\text {salt }}=1$. Continued increase in the dosage of molten salt was unnecessary. On the contrary, a higher addition of salt will dilute the concentrate of the reactant and increase the total dissolved loss of antimony in molten salt, which results in reducing of crude antimony productivity ultimately [14]. Therefore, the appropriate molten salt dosage is $\alpha_{\text {salt }}=1$.

\subsection{Molten Salt Composition}

All experiments were carried out under the following conditions: $100 \mathrm{~g}$ stibnite concentrate, 30 wt. $\%$ coke, $\alpha_{\text {salt }}=1.0, \alpha_{\mathrm{Fe}_{2} \mathrm{O}_{3}}=1.0$, a temperature of $900{ }^{\circ} \mathrm{C}(1173 \mathrm{~K})$, a smelting duration of $180 \mathrm{~min}$. The molten salt composition $W_{\mathrm{NaCl}}: W_{\text {salt }}$ increases from $10 \%$ to $60 \%$. Figure 5 showed the results of the influence of molten salt composition on direct recovery of antimony and on resultant crude antimony grade.

The results implied that direct recovery of antimony raised from $90.78 \%$ to $96.87 \%$ when $W_{\mathrm{NaCl}}: W_{\text {salt }}$ increasd from $10 \%$ to $40 \%$. In addition, crude antimony grade ascended from $78.59 \%$ to $82.45 \%$ gradually. Further increase of $W_{\mathrm{NaCl}}: W_{\text {salt }}$ showed no positive effect on crude antimony grade improvement, even deceased the recovery of antimony. It's because addition of $\mathrm{NaCl}$ is beneficial to decrease melting point of molten salt and increase its fluidity, which causes reductive sulfur-fixing reaction to occur more easily and improves settling efficiency of antimony particles. However, contents of $\mathrm{NaCl}$ in molten salt went beyond $50 \%$, which, on the one hand, intensified the volatilization of molten salt, on the other hand, was more than the eutectic composition of in $\mathrm{Na}_{2} \mathrm{CO}_{3}-\mathrm{NaCl}$ binary system [13], as a result, melting point of binary system ascended, and the fluidity of molten salt decreased evidently. Thus further caused the settling and separation efficiency of antimony particles to be deteriorated. Meanwhile, excessive addition of $\mathrm{NaCl}$ will result in shorten of service life of furnace lining and body. Therefore, in this study, $W_{\mathrm{NaCl}}: W_{\text {salt }}=40 \%$ was selected as the optimized molten salt composition. 


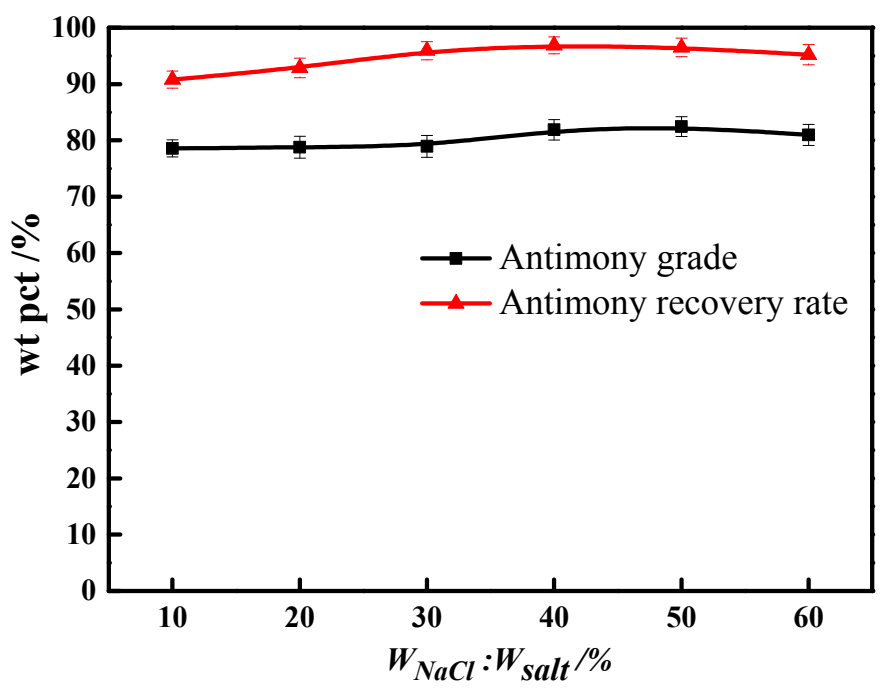

Figure 5. Influence of molten salt composition on the extraction of antimony and crude antimony grade. $\left(\alpha_{\text {salt }}=1.0, \alpha_{\mathrm{Fe}_{2} \mathrm{O}_{3}}=1.0, W_{\text {coke }}: W_{\text {stibnite }}=30 \%, 900{ }^{\circ} \mathrm{C}(1173 \mathrm{~K}), 180 \mathrm{~min}\right)$.

\subsection{Ferric Oxide Dosage}

The curves of effect of addition of sulfur-fixing agent $\mathrm{Fe}_{2} \mathrm{O}_{3}$ on direct recovery of antimony and crude antimony grade were showed in Figure 6. All experiments were carried out under the following conditions: $100 \mathrm{~g}$ stibnite concentrate, $\alpha_{\text {salt }}=1.0, W_{\mathrm{NaCl}}: W_{\text {salt }}=40 \%, 30 \mathrm{wt}$. $\%$ coke, a temperature of $900{ }^{\circ} \mathrm{C}(1173 \mathrm{~K})$, a smelting duration of $180 \mathrm{~min} . \alpha_{\mathrm{Fe}_{2} \mathrm{O}_{3}}$ increases from 0.8 to 1.3 . The results indicated that the direct recovery of antimony basically remained constant at above $95 \%$ and crude antimony grade descended from $81.75 \%$ to $56.76 \%$ as increasing of $\mathrm{Fe}_{2} \mathrm{O}_{3}$ addition. That's because some $\mathrm{Fe}_{2} \mathrm{O}_{3}$ were reduced to metallic $\mathrm{Fe}$ and transferred to crude antimony. Results on the influence of dosage of ferric oxide implied that $\alpha_{\mathrm{Fe}_{2} \mathrm{O}_{3}}=1.0$ is adequate for efficient extraction of antimony.

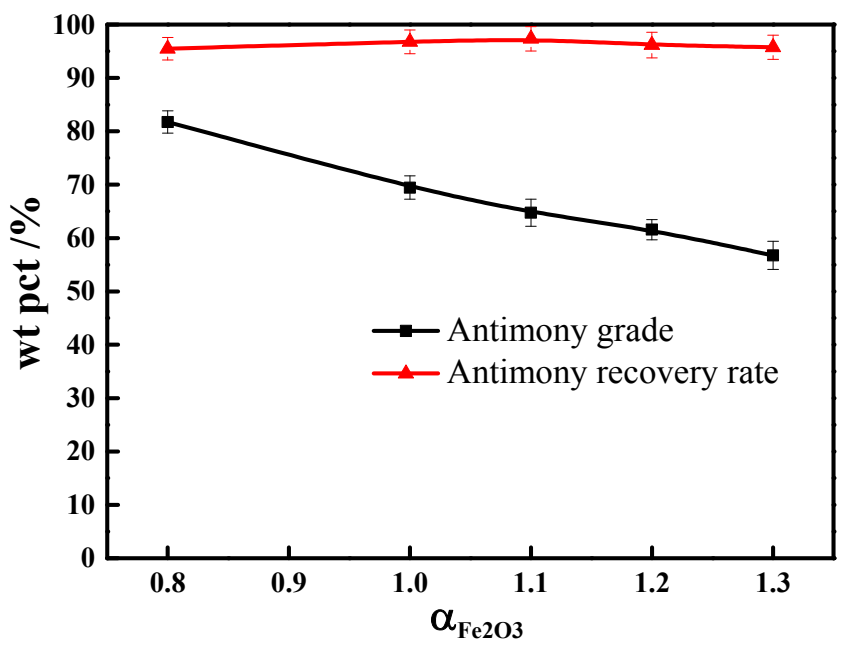

Figure 6. Influence of ferric oxide dosage on the extraction of antimony and antimony grade. $\left(\alpha_{\text {salt }}=1.0\right.$, $\left.W_{\mathrm{NaCl}}: W_{\text {salt }}=40 \%, W_{\text {coke }}: W_{\text {stibnite }}=30 \%, 900{ }^{\circ} \mathrm{C}(1173 \mathrm{~K}), 180 \mathrm{~min}\right)$.

\subsection{Smelting Temperature}

Figure 7 illustrated the influence of temperature on crude antimony grade and direct antimony recovery rate. All experiments were operated under following conditions: $100 \mathrm{~g}$ stibnite concentrate, $\alpha_{\text {salt }}=1.0, W_{\mathrm{NaCl}}: W_{\text {salt }}=40 \%, \alpha_{\mathrm{Fe}_{2} \mathrm{O}_{3}}=1.0,30 \mathrm{wt}$. \% coke, a smelting duration of $180 \mathrm{~min}$. It was 
observed that antimony recovery rate increased steadily from $85.62 \%$ to $95.80 \%$, while crude antimony grade decreased from $87.01 \%$ to $71.86 \%$ with temperature ascending from $800{ }^{\circ} \mathrm{C}(1073 \mathrm{~K})$ to $950{ }^{\circ} \mathrm{C}$ $(1223 \mathrm{~K})$. Excessively low temperature cannot ensure reductive sulfur-fixing reaction is thoroughly positive and resultant metallic antimony particles were difficult to settle as well. However, excessively high temperature will lead to volatilization loss of reactants and rise of energy consumption. Therefore, $850^{\circ} \mathrm{C}(1123 \mathrm{~K})$ is selected as the optimum smelting temperature.

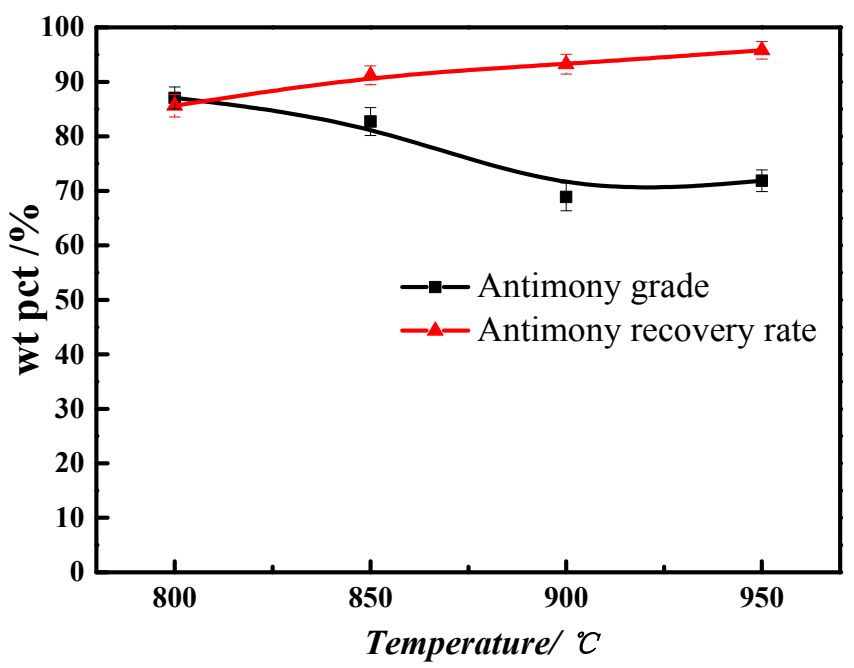

Figure 7. Influence of smelting temperature on the extraction of antimony and antimony grade. $\left(\alpha_{\text {salt }}=1.0, W_{\mathrm{NaCl}}: W_{\text {salt }}=40 \%, \alpha_{\mathrm{Fe}_{2} \mathrm{O}_{3}}=1.0, W_{\text {coke }}: W_{\text {stibnite }}=30 \%, 180 \mathrm{~min}\right)$.

\subsection{Smelting Duration}

The influence of the smelting duration on antimony recovery rate and crude antimony was illustrated in Figure 8. All experiments were carried out under a charging of $100 \mathrm{~g}$ stibnite concentrate and $30 \mathrm{wt}$. \% coke and $\alpha_{\text {salt }}=1.0$, of which $W_{\mathrm{NaCl}}: W_{\text {salt }}=40 \%, \alpha_{\mathrm{Fe}_{2} \mathrm{O}_{3}}=1.0$, smelting at $850{ }^{\circ} \mathrm{C}(1123 \mathrm{~K})$. Smelting duration increased from $60 \mathrm{~min}$ to $240 \mathrm{~min}$. The results implied that the direct recovery of antimony decreased steadily from $92.48 \%$ to $80.15 \%$ and crude antimony grade dropped from $93.1 \%$ to $74.99 \%$ respectively as smelting duration increased from $60 \mathrm{~min}$ to $240 \mathrm{~min}$. It indicated that the reductive sulfur-fixing reaction had sufficiently carried out after $60 \mathrm{~min}$. Continued extension in smelting duration was unnecessary, On the contrary, a prolonged smelting time will caused volatilization loss of antimony and molten salt to increase. In addition, iron oxide will be increasingly reduced into metallic Fe and dilute the crude antimony grade. Accordingly, $60 \mathrm{~min}$ is selected as the optimum smelting duration. 


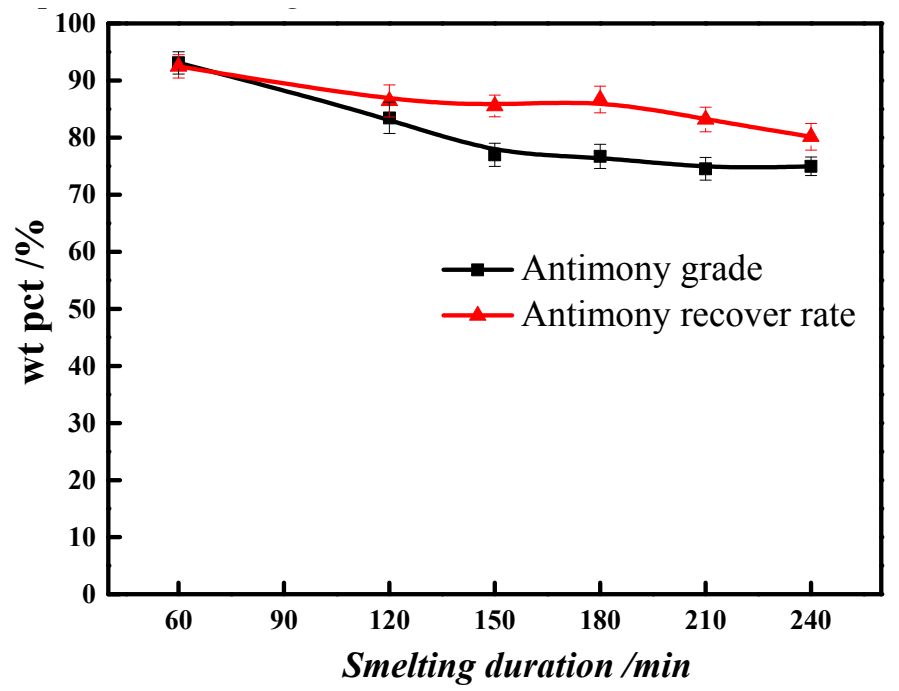

Figure 8. Influence of reaction time on the extraction of antimony and antimony grade. $\left(\alpha_{\text {salt }}=1.0\right.$, $\left.W_{\mathrm{NaCl}}: W_{\text {salt }}=40 \%, \alpha_{\mathrm{Fe}_{2} \mathrm{O}_{3}}=1.0, W_{\text {coke }}: W_{\text {stibnite }}=30 \%, 850{ }^{\circ} \mathrm{C}(1123 \mathrm{~K})\right)$.

\subsection{Reductive Agent Dosage}

The results of effect of reductive agent dosage on crude antimony grade and direct antimony recovery rate were illustrated in Figure 9. All experiments were carried out under the following conditions: $100 \mathrm{~g}$ stibnite, $\alpha_{\text {salt }}=1.0, W_{\mathrm{NaCl}}: W_{\text {salt }}=40 \%, \alpha_{\mathrm{Fe}_{2} \mathrm{O}_{3}}=1.0$, smelting at $850{ }^{\circ} \mathrm{C}(1123 \mathrm{~K})$ for $60 \mathrm{~min}$. The curves showed that resultant crude antimony grade descending from $97.94 \%$ to $88.32 \%$, and direct antimony recovery rate ascended from $50 \%$ to $94.99 \%$ respectively as coke addition increased from $10 \%$ to $50 \%$. Under weak reductive atmosphere, the produce of crude antimony is small because forward reductive sulfur-fixing reaction is not thorough, so that antimony cannot be enriched and recovered completely. Strong reductive atmosphere is beneficial to increase the recovery of antimony. However, the contents of metallic Fe in crude antimony will increase simultaneously. Therefore, $40 \%$ coke dosage was the optimum addition for antimony extraction.

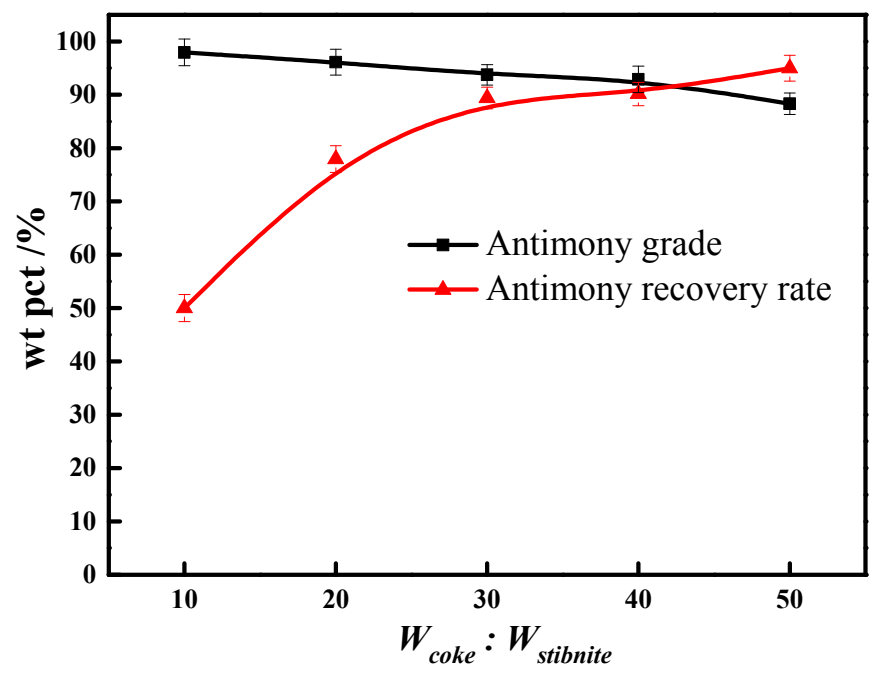

Figure 9. Influence of coke addition on the extraction of antimony and antimony grade. $\left(\alpha_{\text {salt }}=1.0\right.$, $\left.W_{\mathrm{NaCl}}: W_{\text {Salt }}=40 \%, \alpha_{\mathrm{Fe}_{2} \mathrm{O}_{3}}=1.0,850^{\circ} \mathrm{C}(1123 \mathrm{~K}), 60 \mathrm{~min}\right)$. 


\subsection{Confirmation Experiments}

According to results of above tests, the optimum conditions for one-step extraction of antimony in low temperature from stibnite concentrate, using iron oxide as sulfur-fixing agent, were obtained as follow: a smelting temperature of $850{ }^{\circ} \mathrm{C}(1123 \mathrm{~K}), 60 \mathrm{~min}$ smelting duration, 1.0 time stoichiometric requirement $\left(\alpha_{\text {salt }}=1.0\right)$ of mixed sodium salt $\left(\mathrm{Na}_{2} \mathrm{CO}_{3}\right.$ and $\left.\mathrm{NaCl}\right)$, molten salt composition $W_{\mathrm{NaCl}}: W_{\text {salt }}$ $=40 \%, 1.0$ time stoichiometric requirement of ferric oxide $\left(\alpha_{\mathrm{Fe}_{2} \mathrm{O}_{3}}=1.0\right), W_{\text {coke }}: W_{\text {stibnite }}=40 \%$. These optimum conditions were applied in confirmation experiments to extract antimony from $1000 \mathrm{~g}$ stibnite concentrate. The resultant smelting slag was leached in $50^{\circ} \mathrm{C}(323 \mathrm{~K})$ water, $\mathrm{L} / \mathrm{S}=5: 1$, for $3 \mathrm{~h}$. The results of ICP analysis of resultants crude antimony, lixivium and leaching slag were given in Table 3. Figure 10 illustrated the distribution behaviors of main elements in confirmation experiments.

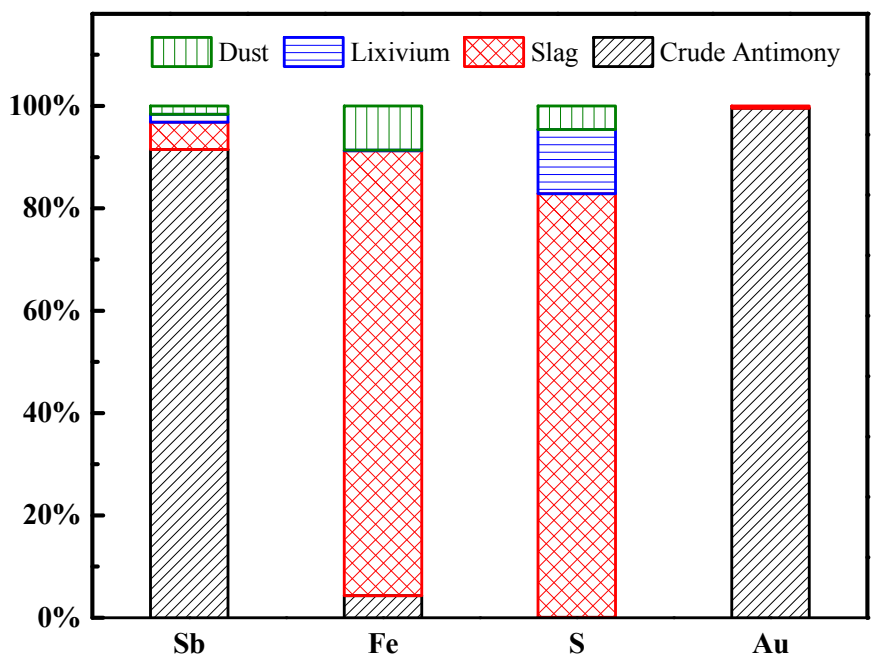

Figure 10. The distribution behaviors of main elements in products during confirmation experiments.

Table 3. Chemical compositions of resultants in confirmation experiments.

\begin{tabular}{|c|c|c|c|c|c|c|c|c|c|c|c|c|c|c|}
\hline \multirow{3}{*}{ No. } & \multicolumn{14}{|c|}{ Chemical Compositions } \\
\hline & \multicolumn{4}{|c|}{ Crude Antimony/\% } & \multicolumn{5}{|c|}{ Slag/\% } & \multicolumn{5}{|c|}{ Lixivium/mg $\cdot \mathrm{L}^{-1}$} \\
\hline & $\mathrm{Sb}$ & $\mathrm{Fe}$ & $\mathrm{Pb}$ & $\mathrm{Au}$ & $\mathrm{Sb}$ & $\mathrm{Fe}$ & $\mathrm{Pb}$ & $\mathrm{S}_{\mathrm{T}}$ & $\mathrm{Na}$ & $\mathrm{Sb}$ & $\mathrm{Fe}$ & $\mathrm{Pb}$ & $\mathrm{S}_{\mathrm{T}}$ & $\mathrm{Na}$ \\
\hline $1 \#$ & 96.7 & 2.29 & 0.55 & 0.03 & 5.46 & 33.67 & 0.09 & 18.5 & 9.26 & 726 & 8.44 & 0.72 & 4642 & $>14000$ \\
\hline 2\# & 95.8 & 2.65 & 0.54 & 0.02 & 5.52 & 34.18 & 0.06 & 19.4 & 8.21 & 715 & 8.80 & 0.67 & 4824 & $>14000$ \\
\hline 3\# & 95.4 & 3.62 & 0.52 & 0.02 & 4.26 & 35.83 & 0.08 & 18.95 & 8.44 & 731 & 8.17 & 0.89 & 5012 & $>14000$ \\
\hline AVG & 96 & 2.85 & 0.54 & 0.02 & 5.08 & 34.56 & 0.08 & 18.95 & 8.64 & 724 & 8.47 & 0.76 & 4826 & $>14000$ \\
\hline
\end{tabular}

It was observed that $91.48 \%$ antimony was directly recovered in crude antimony under the optimum condition. Meanwhile, crude antimony grade could reach $96.00 \%$. Overall, antimony direct recovery attained in confirmation experiments showed a slight decrease around 1\%-3\% compared to the preliminary test results, but still higher than $91 \%$. The crude antimony purity had an increase of about $1 \%-10 \%$ compared to those obtained during preliminary experiments. The impurities in crude antimony were primarily $2.85 \%$ metallic Fe and $0.54 \% \mathrm{~Pb}$ which could be removed easily in following refining process. In addition, 99.55\% Au contained in stibnite concentrate enriched in the crude antimony simultaneously. Sulfur contained in stibnite concentrate was nearly fixed (95.31\%) in the slag. Furthermore, phase compositions of slag and leaching residue were characterized by XRD. The results were showed in Figure 11. 

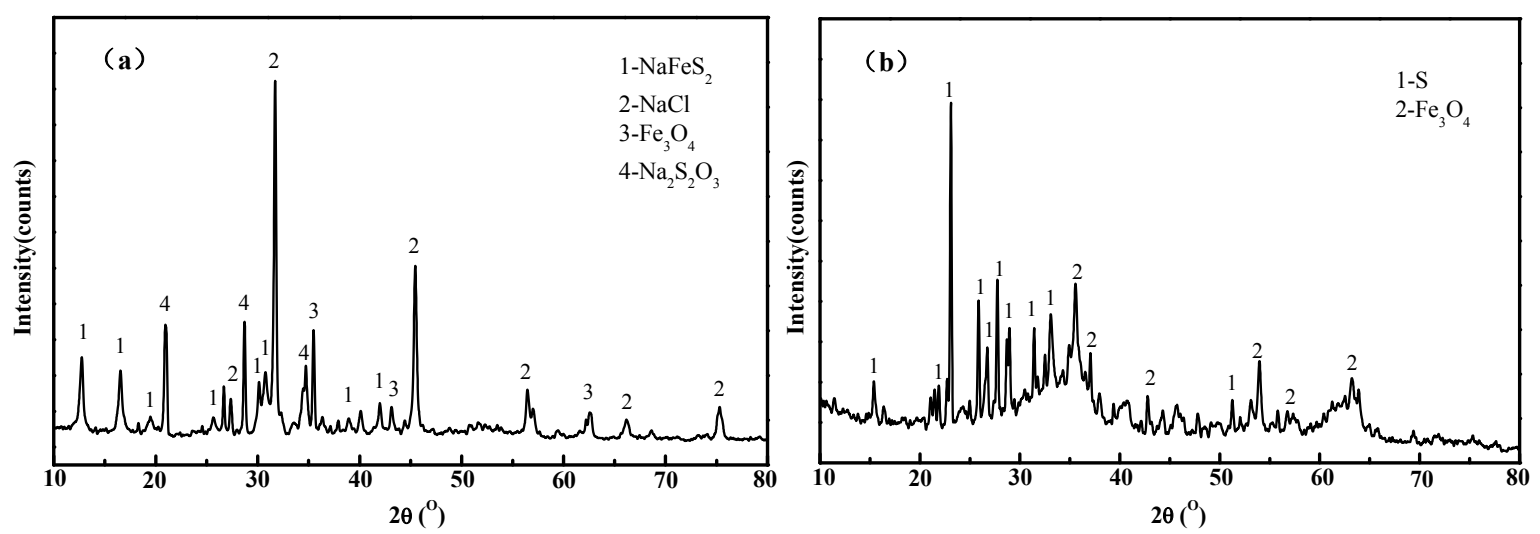

Figure 11. XRD analysis of molten slag and its residue after leaching. (a) molten slag; (b) residue.

It was observed that molten slag primarily comprised $\mathrm{NaFeS}_{2}, \mathrm{NaCl}, \mathrm{Na}_{2} \mathrm{~S}_{2} \mathrm{O}_{3}$ and $\mathrm{Fe}_{3} \mathrm{O}_{4}$. That indicated fraction of $\mathrm{Na}_{2} \mathrm{CO}_{3}$ were involved in sulfur-fixing reaction and generated $\mathrm{Na}_{2} \mathrm{~S}$. The residues after leaching of molten slag mainly contained elemental sulfur (S) and $\mathrm{Fe}_{3} \mathrm{O}_{4}$. It was found that $\mathrm{FeS}$ reacted with $\mathrm{H}_{2} \mathrm{O}$ and generated $\mathrm{S}$. The reaction equation [20] was shown as follow:

$$
\mathrm{FeS}+2 \mathrm{H}_{2} \mathrm{O}=\mathrm{FeOOH}+1.5 \mathrm{H}_{2}(\mathrm{~g})+\mathrm{S}
$$

Resultant $\mathrm{FeOOH}$ would dehydrate and continually be oxidized into $\mathrm{Fe}_{3} \mathrm{O}_{4}$ during drying operation.

\section{Conclusions}

In this study it can be concluded that iron oxides are a kind of high-efficiency alternative sulfur-fixing agent. Thermodynamic analysis and laboratory experimental results also verified the reliability and feasibility of the proposed renovate process. The optimum reductive-sulfur-fixing smelting conditions for one-step extraction of antimony from stibnite concentrate were determined. Under the optimum conditions, the direct recovery rate of antimony can reach $91.48 \%$. Crude antimony with a purity of $96.00 \%$ has been achieved. $95.31 \%$ of sulfur is fixed in form of FeS in the presence of iron oxide, resulting in a process that is free to atmospheric pollution. Furthermore, precious metals contained in stibnite concentrate are enriched and recovered comprehensively in crude antimony. The reaction flux, binary molten slat $\mathrm{Na}_{2} \mathrm{CO}_{3}-\mathrm{NaCl}$, can be regenerated and reused. What's more, the iron-containing secondary materials can be recycled environmentally friendly with economic value through this process.

Acknowledgments: The authors wish to express their thanks to Hunan Province Science and Technology Major Project (Grant No. 2013FJ1009) and the National Natural Science Foundation of China (Grant No. 51234009) for the financial support of this research.

Author Contributions: Haotian Xue and Yun Li performed the experiments and Yun Li wrote the paper under Yongming Chen's guidance, and contributes to all activities.

Conflicts of Interest: The authors declare no conflict of interest.

\section{References}

1. Lei, T.; Zhou, C.J.; Zhang, H.P. Antimony Metallurgy, 1st ed.; Metallurgical Industry Press: Beijing, China, 2012; p. 143.

2. Zhao, T.C. Antimony, 1st ed.; Metallurgical Industry Press: Beijing, China, 1987; pp. 96-99.

3. Wang, J.K.; Lei, T. Treating low grade antimony ore by bath smelting-continuous fuming process (in Chinese). Nonferr. Metall. 2000, 52, 44-48. 
4. Chen, Y.M.; Huang, C.; Tang, M.T.; Yao, W.Y.; Tang, C.B.; Pi, G.H. Production of antimony by directly reducing-matting smelting of stibnite concentrate (in Chinese). Chin. J. Nonferr. Met. 2005, 15, 1311-1316.

5. Ye, L.G.; Tang, C.B.; Tang, M.T.; Yang, J.G.; Chen, Y.M.; Yang, S.H.; He, J. Separation antimony from stibnite concentrate through a low temperature smelting (in Chinese). J. Cent. South Univ. (Sci. Technol.) 2012, 43, 3338-3843.

6. Samuel, A.A.; Åke, S. Selective leaching of arsenic and antimony from a tetrahedrite rich complex sulphide concentrate using alkaline sulphide solution. Miner. Eng. 2010, 23, 1227-1236.

7. Yang, J.Y.; Gao, L.; Yang, J.G. A New Cleaning Hydrometallurgical Technology for Stibnite (in Chinese). Hydrometall. China 2011, 30, 137-146.

8. Liu, W.F.; Yang, T.Z.; Chen, L.; Bin, S.; Bin, W.D. Development of Antimony Smelting Technology in China. In Proceedings of the 4th International Symposium on High-Temperature Metallurgical Processing, San Antonio, TX, USA, February 2013; pp. 341-351.

9. Liu, F.Y.; Le, X.C.; McKnight-Whitford, A.; Xia, Y.L.; Wu, F.C.; Elswick, E.; Johnson, C.C.; Zhu, C. Antimony speciation and contamination of waters in the Xikuangshan antimony mining and smelting area (in Chinese). Chin. Environ. Geochem. Health 2010, 32, 401-413. [CrossRef] [PubMed]

10. Wilson, S.C.; Lockwood, P.V.; Ashley, P.M.; Tighe, M. The chemistry and behaviour of antimony in the soil environment with comparisons to arsenic: A critical review. Environ. Pollut. 2010, 158, 1169-1181. [CrossRef] [PubMed]

11. Tang, M.T.; Tang, C.B.; Chen, Y.M.; Yang, J.G.; Yang, S.H.; He, J.; Ou, Z. A promising low carbon clean metallurgical method-Low-temperature molten salt metallurgy of heavy metal. China Nonferr. Metall. 2010, 4, 49-53.

12. Yang, J.G.; Tang, C.B.; Chen, Y.M.; Tang, M.T. Separation of antimony from a stibnite concentrate through a low-temperature smelting process to eliminate $\mathrm{SO}_{2}$ emission. Metal. Mater. Trans. B 2011, 42, 30-36. [CrossRef]

13. Ye, L.G.; Tang, C.B.; Chen, Y.M.; Yang, S.H.; Tang, M.T. The thermal physical properties and stability of the eutectic composition in a $\mathrm{Na}_{2} \mathrm{CO}_{3}-\mathrm{NaCl}$ binary system. Thermochim. Acta 2014, 596, 14-20. [CrossRef]

14. Ye, L.G.; Tang, C.B.; Chen, Y.M.; Yang, S.H.; Yang, J.G.; Zhang, W.H. One-step extraction of antimony from low-grade stibnite in Sodium Carbonate-Sodium Chloride binary molten salt. J. Clean. Prod. 2015, 93, 134-139. [CrossRef]

15. Smirnov, M.P. Direct smelting of lead at low temperature. Nonferr. Metall. 1990, 5, 34-36.

16. Sun, H.; Sun, T.C.; Gao, E.X.; Liu, Z.H.; Xu, Y. Desulfurization mechanism of calcium salts in direct reduction roasting of pyrite cinder. J. Univ. Sci. Technol. BJ 2013, 35, 977-985.

17. Alp, I.; Deveci, H.; Yazici, E.Y.; Türk, T. Potential use of pyrite cinders as raw material in cement production: Results of industrial scale trial operations. J. Hazard. Mater. 2009, 166, 144-149. [CrossRef] [PubMed]

18. Zhu, D.Q.; Chen, D.; Pan, J.; Süngün, Y.H. One step technology to separate copper, zinc, lead from iron in metallurgical slag and pyrite cinder (I): Laboratory scale test. Miner. Process. Extr. Metall. 2012, 121, $79-85$. [CrossRef]

19. HSC Chemistry; version 6.1; Chemical Reaction and Equilibrium Software with extensive thermochemical database; Outokumpu: Pori, Finland, 2007.

20. Rickard, D. Kinetics of pyrite formation by the $\mathrm{H}_{2} \mathrm{~S}$ oxidation of iron (II) monosulfide in aqueous solutions between 25 and $125^{\circ} \mathrm{C}$ : The rate equation. Geochim. Cosmochim. Acta 1997, 61, 115-134. [CrossRef]

(C) 2016 by the authors; licensee MDPI, Basel, Switzerland. This article is an open access article distributed under the terms and conditions of the Creative Commons Attribution (CC-BY) license (http://creativecommons.org/licenses/by/4.0/). 